\title{
PERAN BMT DALAM PEMBERDAYAAN EKONOMI (STUDI KASUS PADA BMT PADI BERSINAR UTAMA SURABAYA)'
}

\author{
Evi Nur Fitria \\ Departemen Ekonomi Syariah-Fakultas Ekonomi dan Bisnis-Universitas Airlangga \\ Email : evinurfitria@gmail.com \\ A. Syifaul Qulub \\ Departemen Ekonomi Syariah-Fakultas Ekonomi dan Bisnis-Universitas Airlangga \\ Email : syifa_qulub@yahoo.com
}

\begin{abstract}
ABTRACT:
For those who have entered the productive age and are able to work, without high education and business capital, the possible work will be to open employment opportunities in the micro business sector. The role of the small business in practice is constrained by several things, one of which is the problem of capital. This research aims to find out how the role of Baitul Maal Wat Tamt BMT Pinar Bersinar Utama Surabaya towards the economic empowerment of small traders in the Pucang Market Surabaya. The research method used is a qualitative case study approach using data collection techniques carried out by interviews and direct observation to the object of research. The results of this study are Baitul Maal Wat Tamwil has played a role in increasing the business of small traders in the Pucang Market in Surabaya. Business improvement from small traders can be seen from BMT members who trade in the Pucang Market experiencing increased revenue and smooth business from time to time.
\end{abstract}

Keywords: Baitul Maal Wat Tamwil, Economic Empowerment, Financing

\section{PENDAHULUAN}

Di Indonesia, koperasi BMT berdiri pada tahun 1992 yang kemudian didukung Presiden RI yang meluncurkan BMT sebagai gerakan nasional pada tahun 1996. Sejak saat itu, BMT menapak momentumnya dengan berkembang secara nasional.Pada tahun 2000/2001, jumlah BMT yang beroperasi di Indonesia diperkirakan sekitar 3.000 unit (Arifin, 2000: 172, Azis, 2001, dan Republika, 27-06-2008).

Pada awal perkembangannya, BMT memang tidak memiliki badan hukum resmi.BMT berkembang sebagai Kelompok Swadaya Mayarakat (KSM) atau Kelompok Simpan Pinjam (KSP). Namun kemudian oleh lembaga-lembaga pembina BMT yang ada, seperti PINBUK (Pusat Inkubasi Bisnis Usaha Kecil) dan Dompet Dhuafa Republika, BMT diarahkan untuk berbadan hukum koperasi, selain sebagiannya juga Baitul Maalnya mendapatkan pengesahan dari pemerintah sebagai badan hukum LAZIS (Lembaga Amil Zakat, Infaq, dan Shodaqoh). Alasannya, karena BMT berkembang dari kelompok swadaya masyarakat.Selain itu, dengan berbentuk koperasi, BMT dapat berkembang ke berbagai sektor usaha seperti keuangan dan sektor riil. Bentuk ini juga diharapkan dapat memenuhi tujuan memberdayakan masyarakat luas, sehingga kepemilikan kolektif BMT sebagaimana konsep

\footnotetext{
${ }^{1}$ Jurnal ini merupakan bagian dari skripsi yang ditulis oleh Evi Nur Fitria, NIM: 041211431014 , yang diuji pada 16 Juli 2019.
} 
koperasi akan lebih mengenai sasaran (Widodo, 1999: 84-85).

Alasan lain identifikasi BMT sebagai koperasi syariah itu juga karena BMT didirikan dengan semangat kekeluargaan. Karena itu, keanggotaannya bersifat sukarela dan terbuka, yang meniscayakan tidak ada paksaan dan tidak ada diskriminasi keanggotaan. Simpanan pokok khusus BMT sebesar minimal Rp 100.000 - Rp 1.000.000 oleh sekurang-kurangnya 20 orang, sebagaimana koperasi, sehingga bisa terkumpul minimal Rp 10.000.000 - Rp 15.000.000. meskipun demikian, dalam BMT dibolehkan adanya pemodal penggerak dari mana saja, termasuk dari lembaga tertentu, seperti koperasi biasa. Mengingat sifatnya yang kekeluargaan itu, tujuan BMT adalah untuk meningkatkan kualitas ekonomi masyarakat akar rumput dan BMT pun memiliki komitmen moral dan kemanusiaan yang tinggi, jauh dari praktir rentenir yang menghisap.BMT bukan merupakan usaha yang mencari keuntungan sendiri, tetapi senantiasa membantu ekonomi lemah.Oleh sebab itu, dalam BMT jumlah pinjaman yang kecil (di bawah Rp 500.000) tidak mengharuskan menggunakan jaminan (Majid dan Rasyid, 2000: 162-199, 201-201, dan Yazid, 2001).Selain itu, sistem operasional BMT berdasarkan prinsip loss and profit sharing (sistem bagi hasil), untung maupun rugi dibagi bersama.Bahkan, BMT pun memberikan pinjaman lunak (al-qardh al-hasan), dimana peminjam hanya diharuskan membayar biaya administrasi dan mengembalikan pinjaman pokok saja.

Kini, sebagaimana telah disinggung di muka, koperasi syariah BMT sudah sangat tidak masalah lagi secara perundangan. Alasannya, karena sejalan dengan UU No. 17/2012 tentang perkoperasian, UU No. 1/2013 tentang Lembaga Keuangan Mikro (LKM), UU No. 21/2011 tentang Otoritas Jasa Keuangan (OJK) yang juga mengatur perbankan syariah, dan terutama sekali Keputusan Menteri Negara Koperasi dan Usaha KecilMenengah (KepMen) No. 91/2004 tentang petunjuk pelaksanaan Kegiatan Usaha Koperasi Jasa Keuangan Syariah (KJKS).

Ekonomi Islam sebagai suatu alternatif dalam kegiatan bermuamalah di bidang ekonomi mewajibkan umat muslim untuk bertransaksi secara halal dan menghindari sistem riba dan gharar yang menjadi hambatan psikologis bagi umat Islam. BMT merupakan lembaga kevangan mikro Islam non bank yang memiliki peran secara langsung bersentuhan dengan kesejahteraan perekonomian masyarakat pada umumnya dan kesejahteraan perekenomian anggota pada khususnya, dimana BMT melalui pembiayaannya dapat meminimalkan kegiatan spekulasi dalam usaha dan memaksimalkan kemampuan masyarakat dalam bidang produksi dengan pembiayaanpembiayaan yang dilakukan sesuai 
dengan produk-produk yang ditawarkan pada tiap-tiap BMT yang ada.

Termasuk di dalamnya adanya BMT Padi Bersinar Utama yang merupakan satu satunya lembaga keuangan Islam di daerah dekat dengan Pasar Pucang.Dimana, Pasar Pucang merupakan tiang penyangga ekonomi di daerah Pucang. BMT Padi Bersinar Utama merupakan bentukan BMT dari Pimpinan Wilayah Nasyiatul Aisyiyah Jawa Timur merupakan lembaga keuangan mikro syari'ah yang sangat strategis dan layak untuk memfasilitasi perubahan perekonomian rumah tangga rakyat khususnya untuk umat islam menjadi lebih baik atau sejahtera dibandingkan sebelumnya. Disinilah peranan BMT sebagai lembaga keuangan mikro syari'ah, berusaha menjadi mitra bagi usaha kecil dan menengah di kota Surabaya dengan memberikan pendampingan dan juga pembiayaan BMT Padi Bersinar Utama adalah lembaga keuangan yang dikelola oleh Pimpinan Wilayah Nasyiatul Aisyiah Jawa Timur. yang berawal dari kemirisan hati pimpinan wilayah nasyiatul aisyiah melihat merebaknya para rentenir yang beredar dimasyarakat, Koperasi Dinar didirikan pada tahun 1998 oleh 25 anggota nasyiatul aisyiah jawa timur dengan modal awal 5.000.000,- (2.800.000,- dari modal PWNA dan 2.200.000,- dari hasil iuran pendiri) yang berfungsi untuk meningkatkan dan mengembangkan kehidupan dan kesejahteraan sosial ekonomi umat serta sebagai sarana dakwah.

Koperasi BMT DINAR menerapkan sistem kerja yang sesuai dengan syari'ah islam dalam operasionalnya, yaitu menerapkan sistem bagi hasil dan jual beli. Pelayanan dalam transaksi mudah, cepat serta service jemput bola yaitu pelayanan dalam pengambilan dan penyerahan dana setoran/penarikan tabungan, deposito ketempat anggota. Baitul Maal wa Tamwil Pimpinan Wilayah Nasyiatul Aisyiyah Jawa Timur merupakan lembaga keuangan mikro syari'ah yang sangat strategis dan layak untuk memfasilitasi perubahan perekonomian rumah tangga rakyat khususnya untuk umat islam menjadi lebih baik atau sejahtera dibandingkan sebelumnya. Disinilah peranan BMT sebagai lembaga keuangan mikro syari'ah, berusaha menjadi mitra bagi usaha kecil dan menengah di kota Surabaya dengan memberikan pendampingan dan juga pembiayaan dengan pola sesuai syari'at islam.

Jumlah anggota BMT ada sekitar 300 orang yang aktif, anggota luar biasa 2 lembaga, dan calon anggota 4 orang.Anggota BMT Dinar Utama didominasi oleh masyarakat sekitar kelurahan kertajaya, terutama pedagang di area Pasar Pucang, anggota NA, dan beberapa referensi anggota exsisting. Modal BMT Dinar Utama berasal dari modal sendiri dan modal tidak tetap dengan perincian yang ada pada tabel 
sebagai berikut :

Tabel 1.

PERINCIAN MODAL BMT DINAR UTAMA

(MODAL SENDIRI)

\begin{tabular}{|l|c|}
\hline PWNA & Rp 65.306.840,- \\
\hline $\begin{array}{l}\text { Simpanan } \\
\text { Pokok }\end{array}$ & Rp 27.485.000,- \\
\hline $\begin{array}{l}\text { Simpanan } \\
\text { Wajib }\end{array}$ & Rp 95.391.900,- \\
\hline Cadangan & Rp 147.950.530,- \\
\hline Donasi & Rp 12.848.215,-- \\
\hline SHU & Rp 100.794.180,- \\
\hline al Modal & 449.776 .665 \\
\hline
\end{tabular}

Sumber: Data Primer (2017)

Tabel 2.

\section{PERINCIAN MODAL BMT DINAR}

UTAMA (MODAL TIDAK TETAP)

\begin{tabular}{|l|l|}
\hline $\begin{array}{l}\text { Simpanan } \\
\text { Harian }\end{array}$ & Rp 413.105.086,- \\
\hline $\begin{array}{l}\text { Simpanan } \\
\text { Parcel }\end{array}$ & Rp 321.252.000,- \\
\hline $\begin{array}{l}\text { Simpanan } \\
\text { Qurban }\end{array}$ & Rp 6.100.000,- \\
\hline $\begin{array}{l}\text { Dana } \\
\text { Pendidikan }\end{array}$ & Rp 6.195.860,- \\
\hline $\begin{array}{l}\text { Total } \\
\text { Tidak Tetap }\end{array}$ & Rp 746.652.294,- \\
\hline Omset 2016 & Rp 1.617.730.000,- \\
\hline Asset & Rp 1.444.434.167,- \\
\hline SHU 2016 & Rp 100.794.180,- \\
\hline
\end{tabular}

Sumber : Data Primer (2017)

Di Surabaya khususnya di daerah

Pucang, yang berawal dari keprihatinan pendiri melihat kondisi masyarakat di sekitar daerah Pucang yang notabene daerah tersebut adalah dekat dengan
Pasar Pucang, dimana Pasar tersebut adalah pasar yang besar dan menjadi tombak atau pusat perdagangan dan juga sebagai lahan tempat mencari nafkah untuk penduduk sekitar. Sebagian besar masyarakat yang tinggal di daerah tersebut menggantungkan nasib mereka dengan keberadaan Pasar Pucang, dimana mereka sebagian besar bekerja sebagai pedagang kecil di Pasar Pucang. Dan dahulunya belum ada lembaga keuangan syariah di daerah tersebut, maka sebagian besar masyarakat disana untuk mencari tambahan modal sebagai upaya untuk mengembangkan usahanya adalah dengan cara meminjam vang ke rentenir. Karena mengingat masyarakat yang ada disana adalah pedagang kecil jadi sangat sulit untuk meminjam ke bank yang prosedur administrasinya sulit dan mereka sendiripun tidak begitu memahami bagaimana prosedur dan tata caranya.

Kawasan Gubeng Kertajaya adalah sebuah dusun yang berada di Kelurahan Gubeng Kecamatan Gubeng Kota Surabaya. Dan kawasan Gubeng Kertajaya berbatasan dengan empat dusun yaitu sebelah timur berbatasan dengan dusun Gubeng Airlangga, sebelah barat berbatasan dengan Jalan Jawa, sebelah utara berbatasan dengan dusun Gubeng Klingsingan, sebelah selatan berbatasan dengan dusun Juwingan. Dari sudut geografisnya potensi GubengKertajaya sangat menguntungkan karena letaknya yang 
dekat dengan kelurahan, kecamatan, dan sarana-sarana umum, seperti pasar, swalayan, pertokoan, kios perorangan, toko, warung serba ada, warung kopi dan lain sebagainya maka akan memungkinkan terjadinya suatu kelancaran dalam bidang perekonomian. Tingkat sosial masyarakat daerah Kertajaya tergolong variatif ada yang kaya, miskin, dan ada yang sedang. Sebagian besar masyarakat disana adalah pedagang yang berdagang di Pasar Pucang karena pasar tersebut merupakan pusat perdagangan di daerah sana dan pasarnya pun tergolong pasar yang besar. Terbatasnya sumber modal untuk berdagang, membuat sebagian besar masyarakat di daerah situ berusaha untuk mencari pinjaman atau tambahan modal untuk memenuhi kebutuhan sehari hari dan sebagai persaingan usaha, yang pada akhirnya membuat sebagian orang membuka jasa peminjaman vang yang tidak halal atau bisa kita sebut sebagai rentenir, dan juga kebiasaan yang buruk lainnya seperti sikap konsumtif. Berangkat dari keadaan seperti itu, sehingga wajar jika para pendiri BMT Dinar Utama ingin memberantas hal buruk yang terjadi di daerah tersebut melalui perannya sebagai sarana dakwah perekonomian Islam dan menolong masyarakat dari jerat rentenir.

Dengan berbagai pertimbangan yang matang, para pendiri BMT Padi Bersinar Utama yang merupakan lembaga keuangan yang dikelola oleh
PWNA (Pimpinan Wilayah Nasyiatul Aisyah) Jawa Timur yang merupakan milik dari organisasi Muhammadiyah terinspirasi membentuk BMT Padi Bersinar Utama Surabaya yang berada di kawasan Pasar Pucang Surabaya yang tepatnya berada di Jalan Pucangan III Nomor 107 Surabaya. Hal ini dilakukan dengan harapan mampu meminimalisir bahkan mampu menghapus kebiasan-kebiasaan yang kurang tepat seperti halnya meminimalisir adanya rentenir, mengurangi sifat konsumtif, memberikan edukasi tentang lembaga keuangan mikro syariah, dan lain sebagainya. Selain hal tersebut, tujuan lain adalah diharapkan untuk menampung sedikit demi sedikit hasil yang diperoleh masyarakat sehingga penghasilan itu mampu berotasi atau cenderung tidak diam akan tetapi berputar dalam hal kebaikan. Hal ini dapat dimulai dari hal kecil seperti menyisihkan uang disetiap harinya untuk keperluan hari kedepan yang sekiranya amat membutuhkan pengeluaran ataupun kebutuhan yang tidak diperkirakan. Dan uang yang terkumpul di BMT pun akan diberdayakan kedalam kegiatan-kegiatan positif lainnya, sehingga dana yang terkumpul tidak disimpan begitu saja, akan tetapi akan mengalami perputaran atau rotasi yang statis, dinamis, dan terencanakan.

Beranjak dari keprihatinan pendiri itulah, pendiri berharap dan optimis mampu memberikan manfaat dan hasil yang positif bagi masyarakat di sekitar 
daerah Pasar Pucang mengingat di daerah tersebut belum ada lembaga kevangan syariah dan BMT Padi Bersinar Utama ini merupakan satu satunya lembaga keuangan syariah yang dekat dengan Pasar Pucang tersebut. Pendiri berharap dengan didirikannya BMT Padi Bersinar Utama mampu memberikan peranan yang baik dalam perubahan perekonomian umat khususnya yang ada di daerah Pasar Pucang Surabaya dan alangkah baiknya lagi jika hal ini merambah lebih luas dan lebih bermanfaat bagi khalayak banyak.

BMT Padi Bersinar Utama didirikan atas dasar rasa keprihatinan, dan empati terhadap masyarakat kalangan bawah, dan pengusaha kecil yang sulit memperoleh modal dan untuk menjadikan fasilitas bagi nasabah BMT pada khususnya, ataupun masyarakat sekitar Pasar Pucang dalam memperoleh dan memutarkan modal yang didasari oleh prinsip-prinsip bagi hasil, jual beli, dan titpan. BMT Padi Bersinar Utama sebagai salah satu jembatan bagi semua kalangan masyarakat untuk meningkatkan kesejahteraan, pengembangan, dan pembangunan di bidang perekonomian umat.BMT ini diperuntukkan bagi semua elemen masyarakat, bukan untuk salah satu kalangan masyarakat saja.

Adapun tujuan didirikannya BMT Padi Bersinar Utama adalah menyelenggarakan berbagai pelayanan dan jasa kepada masyarakat, yaitu menyediakan pelayanan nasabah tabungan, deposito, dan pembiayaanpembiayaan.Semua produk pelayanan dan jasa di BMT dilakukan menurut ketentuan syariat Islam yakni bagi hasil.

BMT Padi Bersinar Utama ingin menjembatani masyarakat dalam mewujudkan masyarakat yang berdaya dan ingin menjadi peranan bagi masyarakat dalam meningkatkan perekonomian.Sehinnga masyarakat mampu mengelola dan mengembangkan keuangannya dengan baik, benar, dan tepat sesuai dengan kebutuhan-kebutuhan primer masyarakat. Kehadiran BMT Padi Bersinar Utama diharapkan mampu merambah semua kalangan masyarakat dan menarik masyarakat untuk berpartisipasi dalam proses berjalannnya BMT Padi Bersinar Utama. Dengan adanya BMT Padi Bersinar Utama yang merupakan lembaga kevangan syariah satu-staunya di kawasan daerah Pasar Pucang menjadi salah satu daya tarik untuk diteliti mengenai peranan BMT Padi Bersinar Utama seperti apa dan bagaimana dalam meningkatkan kesejahteraan ekonomi umat melalui program program yang ada di dalamnya.

BMT Padi Bersinar Utama Surabaya adalah lembaga keuangan yang dikelola oleh PWNA Jawa Timur.BMT Padi Bersinar Utama Surabaya adalah sebuah jelmaan dari BMT Padi Bersinar Utama PWNA yang dirintis sejak bulan Maret 1998.BMT Padi Bersinar Utama dalam operasionalnya 
bekerjasama dengan koperasi As Sakinah

Sidoarjo.Selain itu BMT Padi Bersinar Utama juga mempunyai koperasi binaan yaitu BMT Dinar Bojonegoro (BUANA PDNA Kabupaten Bojonegoro).

\section{LANDASAN TEORI}

\section{Definisi Peran}

Istilah peran dalam "Kamus Besar Bahasa Indonesia" mempunyai arti pemain sandiwara (film), tukang lawak pada permainan makyong, perangkat tingkah yang diharapkan dimiliki oleh orang yang berkedudukan di masyarakat. Menurut Ahmadi (1982), peran adalah suatu kompleks pengharapan manusia terhadap caranya individu harus bersikap dan berbuat dalam situasi tertentu yang berdasarkan status dan fungsi sosialnya.

Pengertian peran menurut Soekanto (2009:213), yaitu peran merupakan aspek dinamis kedudukan (status), apabila seseorang melaksanakan hak dan kewajibannya sesuai dengan kedudukannya, maka ia menjalankan suatu peranan. Pendapat lain tentang peran yang telah ditetapkan sebelumnya disebut sebagai peranan normatif. Sebagai peran normatif dalam hubungannya dengan tugas dan kewajiban dinas perhubungan dalam penegakan hukum mempunyai arti penegakan hukum secara total enforcement, yaitu penegakan hukum secara penuh. Sedangkan peran ideal, dapat diterjemahkan sebagai peran yang diharapkan dilakukan oleh pemegang peranan tersebut. Misalnya dinas perhubungan sebagai suatu organisasi formal tertentu diharapkan berfungsi dalam penegakan hukum dapat bertindak sebagai pengayom bagi masyarakat dalam rangka mewujudkan ketertiban, keamanan yang mempunyai tujuan akhir kesejahteraan masyarakat, artinya peranan yang nyata. Hakekatnya peran juga dapat dirumuskan sebagai suatu rangkaian perilaku tertentu yang ditimbulkan oleh suatu jabatan tertentu.Kepribadian seseorang juga mempengaruhi bagaimana peran itu harus dijalankan. Peran yang dimainkan hakekatnya tidak ada perbedaan, baik yang dimainkan atau diperankan pimpinan tingkat atas, menengah maupun bawah akan mempunyai peran yang sama. Peran merupakan tindakan atau perilaku yang dilakukan oleh seseorang yang menempati suatu posisi di dalam status sosial, Soekanto (2002:243), syarat-syarat peran mencangkup tiga hal, yaitu:

1. Peran meliputi norma-norma yang dihubungkan dengan posisi atau tempat seseorang dalam masyarakat, peranan dalam arti ini merupakan rangkaian peraturan-peraturan yang membimbing seseorang dalam kehidupan kemasyarakatan.

2. Peran adalah suatu konsep perilaku apa yang dapat dilaksanakan oleh individu-individu dalam masyarakat sebagai organisasi.

3. Peran juga dapat dikatakan sebagai perilaku individu, yang penting bagi 
struktur sosial masyarakat. (Soekanto, 1982:238)

\section{Sejarah dan Pengertian Baitul Mal Wat Tamwil}

Baitul Mal pertama kali dirumuskan dan didirikan oleh Rasulullah SAW dengan sangat sederhana.Baitul Mal lebih mempunyai pengertian sebagai pihak (aljihat) yang menangani setiap harta benda kaum muslimin, baik berupa pendapatan maupun pengeluaran. Hal tersebut dibuktikan dengan riwayatriwayat yang menyebutkan pendelegasian tugas Baitul Mal oleh Rasulullah SAW kepada beberapa orang sahabat tertentu, seperti tugas pencatatan, tugas penghimpunan zakat hasil pertanian, tugas pemeliharaan zakat hasil ternak, dan juga pendistribusian. Hal itu menjadi landasan yang kuat bagi Baitul Mal sudah ada sejak zaman Rasulullah SAW sekalipun belum dalam bentuk institusi yang baku. Selanjutnya, dimasa pemerintahan Abu Bakar tidak terlalu ada perubahan yang besar berkaitan dengan Baitul Mal. (Qadim, 1983:25|

\section{Ciri-ciri Baitul Mal Wat Tamwil}

Secara umum BMT mempunyai ciriciri sebagai berikut:

1. Merupakan lembaga ekonomi bukan bank yang dapat dijangkau dan mampu menjangkau nasabah kecil atau mikro yang beroprasi secara syariah dengan potensi jaminan dari dalam atau sekitar lingkungannya sendiri.
2. Merupakan gabungan dari kegiatan Baitul Tamwil dan Baitul Maal.

3. BMT berusaha untuk mengumpulkan dana dan anggota dan menyalurkan kepada anggota untuk modal usaha produktif.

4. Baitul maal menerima zakat, infaq, shodaqoh dan menyalurkan kepada asnafnya menurut ketentuan syariah dengan perkiraan pemanfaatan yang paling produktif dan paling bermanfaat.

5. Berorientasi bisnis, mencari laba bersama, dan meningkatkan pemanfaatan yang paling produktif dan paling bermanfaat.

6. Ditumbuhkan dari bawah berlandaskan peran serta masyarakat disekitarnya.

7. Milik bersama masyarakat bawah dan masyarakat di sekitar BMT bukan milik perseorangan atau orang di luar masyarakat.

Sedangkan secara khusus sebagaimana dijelaskan Ridwan (2004:132), BMT memiliki ciri-ciri sebagai berikut:

1. Staf dan karyawan BMT bertindak aktifproaktif, tidak menunggu tetapi menjemput bola, bahkan merebut bola, baik untuk menghimpun dana anggota maupun untuk pembiayaan.

2. Kantor dibuka dalam waktu tertentu yang ditetapkan sesuai kebutuhan pasar.

3. BMT mengadakan pendampingan usaha anggota. 


\section{Fungsi Baitul Mal Wat Tamwil}

Fungsi dari aktifitas yang dijalankan oleh BMT sebagai upaya kongkrit pencapaian tujuan yang diharapkan yang telah dijelaskan di atas. Ridwan (2004:131) menjelaskan Baitul Mal Wat Tamwil berfungsi sebagai :

1. Pengembangan potensi ekonomi masyarakat dan anggotanya untuk mencapai kesejahteraan.

2. Peningkatan kualitas SDM anggota menjadi lebih profesional dan islami.

3. Sebagai perantara keuangan baik fungsi Maal maupun Tamwil untuk usaha produktif.

\section{Peran Baitul Mal Wat Tamwil}

Dalam rangka mencapai tujuannya, BMT memiliki peran sebagai berikut :

1. Mengidentifikasi, memobilisasi, mendorong, dan mengembangkan potensi ekonomi anggota, kelompok muamalat, dan daerah kerjanya.

2. Meningkatkan kualitas SDI (Sumber Daya Insani) anggota menjadi lebih profesional dan islami sehingga semakin kuat dalam menghadapi persaingan global.

3. Menggalang dan memobilisasi potensi masyarakat dalam rangka meningkatkan kesejahteraan anggota.

4. Menjadi perantara keuangan (financial intermediary) di antaranya sebagai shohibul maal dengan duafa sebagai mudharib, terutama untu dana-dana sosial seperti zakat, infaq, sedekah, wakaf, dan hibah.

\section{Prinsip Operasional Baitul Mal Wat Tamwil}

Prinsip-prinsip operasional Baitul Mal Wat Tamwil tidak jauh berbeda dengan yang digunakan oleh Bank Islam. Ridwan (2004:29), menjelaskan sedikitnya tiga prinsip operasional Baitul Mal Wat Tamwil sebagai berikut :

1. Prinsip Bagi Hasil

2. Prinsip Jual Beli dengan Keuntungan (Mark Up)

3. Prinsip Non-Profit

\section{Produk-Produk Baitul Mal Wat Tamwil}

Produk-produk yang dihasilkan oleh BMT sangat banyak.Produk-produk yang dihasilkan tersebut berupa produk penghimpunan maupun produk penyaluran. Menurut Muhammad (2006:32) produk inti dari BMT terdiri atas produk penghimpunan dana (funding) dan produk penyaluran dana (lending).

1. Produk Penghimpun Dana (Funding)

2. Produk Penyaluran Dana (Lending)

\section{Usaha Mikro dan Kecil}

Tingkat kepuasan dan kesejahteraan adalah dua pengertian yang saling berkaitan.Tingkat kepuasan merujuk pada keadaan individu atau kelompok, sedangkan tingkat kesejahteraan mengacu kepada keadaan komunitas atau masyarakat luas.Kesejahteraan adalah kondisi agregat dari kepuasan individu-individu.

Konsep kesejahteraan menurut Nasikun (1996:78) dapat dirumuskam sebagai padanan makna dari konsep 
martabat manusia yang dapat dilihat dari 4 indikator, yaitu : 1. Rasa aman (security), 2. Kesejateraan (welfare), 3.Kebebasan (freedom), 4.Jati diri (identity).

Todaro (2003:34) mengemukakan bahwa kesejahteraan masyarakat menengah ke bawah dapat direpresentasikan dari tingkat hidup masyarakat.Tingkat hidup masyarakat ditandai dengan berkurangnya kemiskinan, tingkat kesehatan yang lebih baik, perolehan tingkat pendidikan yang lebih tinggi, dan tingkat produktivitas masyarakat.

\section{Usaha Mikro dan Kecil}

Dalam Pasal 1 Bab 1, UndangUndang Nomor 20 Tahun 2008 tentang UMKM, usaha mikro didefinisikan sebagai : usaha produktif yang memenuhi kriteria usaha mikro sebagaimana diatur dalam undang-undang tersebut. Sedangkan usaha kecil adalah usaha ekonomi produktif yang berdiri sendiri, yang dilakukan orang perorangan atau badan usaha yang bukan merupakan anak perusahaan atau bukan cabang perusahaan yang dimilki, dikuasai, atau menjadi bagian baik langsung, maupun tidak langsung dari usaha menengah atau usaha besar yang memenuhi kriteria usaha kecil sebagaimana dimaksud dalam Undang-Undang tersebut.

\section{Kriteria Usaha Mikro dan Kecil}

Berdasarkan Undang-Undang Republik Indonesia Nomor 20 Tahun 2008 tentang usaha mikro, kecil, dan menengah. Di dalam bab IV pasal 6 dijelaskan mengenai kriteria usaha mikro dan kecil adalah sebagaimana dibawah ini :

(1) Kriteria Usaha Mikro adalah sebagai berikut :

a. memiliki kekayaan bersih paling banyak Rp 50.000.000,00 (lima puluh juta rupiah) tidak termasuk tanah, dan bangunan tempat usaha; atau

b. memiliki hasil penjualan tahunan paling banyak Rp 300.000.000,00 (tiga ratus juta rupiah).

(2) Kriteria Usaha Kecil adalah sebagai berikut :

a. memiliki kekayaan bersih lebih dari Rp 50.000.000,00 (lima puluh juta rupiah) sampai dengan paling banyak Rp 500.000.000,00 (lima ratus juta rupiah) tidak termasuk tanah dan bangunan tempat usaha; atau

b. memiliki hasil penjualan tahunan lebih dari Rp 300.000.000,00 (tiga ratus juta rupiah) sampai dengan paling banyak Rp 2.500.000.000,00 (dua milyar lima ratus juta rupiah).

(3) Kriteria sebagaimana dimaksud pada ayat (1) huruf $a$, huruf b, dan ayat (2) huruf $a$, huruf b nilai nominalnya dapat diubah sesuai dengan perkembangan perekonomian yang diatur dengan Peraturan Presiden.

\section{Keunggulan Usaha Mikro dan Kecil}

Usaha kecil juga memiliki nilai strategis bagi perkembangan perekonomian negara kita, antara lain sebagai berikut : 
(1) Banyaknya produk-produk tertentu yang dikerjakan oleh perusahaan kecil. Perusahaan besar dan menengah banyak bergantung kepada perusahaan kecil, karena jika hanya dikerjakan oleh perusahaan besar dan menengah, marginnya akan menjadi tidak ekonomis.

(2) Merupakan pemerataan konsentrasi dari kekuatan-kekuatan ekonomi dalam masyarakat.

\section{Kelemahan Usaha Mikro dan Kecil}

Kelemahan maupun hambatan dalam pengelolaan usaha kecil umumnya berkaitan dengan faktor intern dari usaha kecil itu sendiri. Kelemahan maupun hambatan-hambatan tersebut adalah sebagai berikut :

(1) Terlalu banyak biaya yang dikeluarkan, hutang yang tidak bermanfaat, dan tidak mematuhi ketentuan pembukuan standart.

(2) Tidak mengetahui secara tepat berapa kebutuhan modal kerja karena tidak adanya perencanaan kas.

(3) Sering terjadi miss manajemen dan ketidakpedulian pengelolaan terhadap prinsip-prinsip manajerial.

(4) Sumber modal yang terbatas pada kemampuan pemilik.

Adapun yang menyangkut faktor ekstern dari kendala atau hambatan usaha mikro dan kecil antara lain:

(1) Resiko dan hutang-hutang kepada pihak ketiga ditanggung oleh kekayaan pribadi pemilik.
(2) Sering kekurangan informasi bisnis, hanya mengacu kepada intuisi dan ambisi pengelola, serta lemah dalam promosi.

(3) Tidak pernah melakukan studi kelayakan dan penelitian pasar.

\section{Kendala Usaha Mikro dan Kecil}

Kendala-kendala yang umum tersebut termasuk keterbatasan modal kerja, kesulitan-kesulitan dalam pemasaran, distribusi dan pengadaan bahan baku, keterbatasan akses ke informasi mengenai peluang pasar dan lainnya, keterbatasan pekerja dengan keahlian tinggi (kualitas SDM rendah) dan kemampuan teknologi, biaya transportasi dan energi yang tinggi.

\section{Karakteristik Usaha Mikro}

Menurut Sofiah (2011: 210) menyatakan secara umum sektor usaha mikro dan kecil memiliki karakteristik sebagai berikut:

(1) Sistem pembukuan yang relative sederhana dan cenderung tidak mengikuti kaidah administrasi pembukuan standart.

(2) Margin yang cenderung tipis mengingat persaingan yang sangat tinggi.

(3) Modal terbatas.

\section{Definisi Pemberdayaan}

Menurut Ginandjar Kartasasmita, pemberdayaan adalah upaya untuk membangun daya manusia dengan memotivasi, membangkitkan kesadaran akan potensi yang dimiliki masyarakat dan berupaya mengembangkannya. 
Sedangkan menurut Imang Kiasnur Burhan, mendefinisikan pemberdayaan umat atau masyarakat sebagai upaya membangkitkan potensi umat ke arah yang lebih baik, baik dalam kehidupan sosial, politik, maupun ekonominya. Jadi yang dimaksud dengan pemberdayaan disini adalah upaya yang dilakukan BMT Padi Bersinar Utama (Dinar) dalam rangka untuk membangkitkan dan/atau mengembangkan potensi yang dimiliki masyarakat untuk meningkatkan perekonomian mereka melalui pembiayaan sektor ril yang diberikan oleh BMT Dinar serta memberikan keterampilan dan kesadaran maupun memotivasi masyarakat agar menghindari bahaya dari peminjaman pembiayaan kepada rentenir.

\section{Pemberdayaan Ekonomi}

Pemberdayaan menurut bahasa berasal dari kata daya yang berarti tenaga atau kekuatan, proses, cara, perbuatan memberdayakan. Pemberdayaan adalah upaya yang membangun daya masyarakat dengan mendorong, memotivasi, dan membangkitkan kesadaran akan potensi yang dimiliki serta berupaya untuk mengembangkannya.

Ada dua upaya agar pemberdayaan ekonomi masyarakat bisa dijalankan, diantaranya pertama, mempersiapkan pribadi masyarakat menjadi wirausaha.Karena kiat Islam yang pertama dalam mengatasi masalah kemiskinan adalah dengan bekerja.
Dengan memberikan bekal pelatihan, akan terjadi bekal yang amat penting ketika akan memasuki dunia kerja.

Program pembinaan untuk menjadi seorang wiraswasta ini dapat dilakukan melalui beberapa tahap kegiatan, diantaranya memberikan bantuan motivasi moriil.Bentuk motivasi moriil ini berupa penerangan tentang fungsi, hak, dan kewajiban manusia dalam hidupnya yang pada intinya manusia diwajibkan beriman, beribadah, bekerja, dan berikhtiar dengan sekuat tenaga sedangkan hasil akhir dikembalikan kepada Allah SWT.

\section{Pemberdayaan Dalam Islam}

Secara

terminologis pengembangan atau pemberdayaan masyarakat Islam berarti mentransformasikan dan membentuk semua segi ajaran Islam dalam kehidupan kelvarga, kelompok sosial dan masyarakat. Maka demikian, pengembangan atau pemberdayaan masyarakat Islam merupakan model empiris pengembangan perilaku individual dan kolektif dalam dimensi amal shaleh, dengan titik tekan pada pemecahan masalah yang dihadapi masyarakat. Sasaran individual yaitu setiap individu muslim, dengan orientasi pengembangan sistem masyarakat. Sasaran institusional adalah organisasi Islam dan pranata sosial kehidupan, dengan orientasi pengembangan kualitas dan islamitas kelembagaan.

\section{Tujuan Pemberdayaan}


Suharto (2005:58) menyatakan

bahwa tujuan dari pemberdayaan ekonomi adalah sebagai berikut :

a) memenuhi kebutuhan dasar masyarakat sehingga mereka memiliki kebebasan.

b) Menjangkau sumber-sumber produktif yang memungkinkan mereka dapat meningkatkan pendapatan dan memperoleh barang dan jasa yang diperlukan dengan murah dan mudah.

c) Berpartisipasi dalam proses pembangunan dan keputusankeputusan mereka.

Indikator Peningkatan Usaha Pedagang Kecil

Menurut Suryana (2003:85) suatu usaha dikatakan berhasil apabila setelah jangka waktu tertentu usaha tersebut mengalami peningkatan baik dalam permodalan, pendapatan, volume penjualan, output produksi dan tenaga kerja. Maka, peningkatan usaha dapat disamakan dengan keberhasilan usaha. Keberhasilan usaha juga diidentikkan dengan perkembangan perusahaan, yaitu proses peningkatan kuantitas dan dimensi perusahaan. Perkembangan perusahaan adalah pertambahan karyawan, peningkatan aset, omset penjualan, dan lain-lain (Jakarsih, 2008). Hal ini ditandai indikator, antaara lain

1. Peningkatan Aset Usaha

2. Peningkatan omzet penjualan

3. Peningkatan Pendapatan Usaha

4. Stabilitas Usaha

5. Modal Usaha

\section{Pembiayaan}

Dalam Peraturan Menteri Koperasi dan Usaha Kecil dan Mennegah Republik Indonesia Nomor 16/Per/M.KUKM/IX/2015 tentang Pelaksanaan Kegiatan Usaha Simpan Pinjam dan Pembiayaan Syariah oleh koperasi, pembiayaan adalah penyediaan dana atau tagihan yang dipersamakan dengan itu berupa :

1. Transaksi bagi hasil dalam bentuk mudharabah dan musyarakah

2. Transaksi sewa menyewa dalam bentuk ijarah atau sewa beli dalam bentuk ijarah muntahiya bit tamlik

3. Transaksi jual beli dalam bentuk piutang murabahah, salam, dan istishna

4. Transaksi pinjam meminjam dalam bentuk piutang Qardh

5. Transaksi sewa menyewa jasa dalam bentuk ijarah untuk transaksi multijasa

Pembiayaan menurut Muhammad Ridwan dalam bukunya yang berjudul "Manajemen Baitul Maal Wat Tamwil (BMT)", penyediaan uang atau yang dapat dipersamakan dengan itu berdasarkan tujuan atau kesepakatan pinjam meminjam antara BMT dengan pihak lain yang mewajibkan pihak meminjam untuk melunasi hutangnya setelah jangka waktu tertentu ditambah dengan sejumlah imbalan atau pembagian hasil.

\section{Prinsip-prinsip Pembiayaan Islam}

Untuk menyesuaikan dengan aturan-aturan dan norma-norma Islam, empat segi religius yang berkedudukan 
kuat dalam literatur harus diterapkan dalam perilaku investasi.empat segi tersebut adalah :

a. Tidak ada transaksi kevangan berbasis bunga (riba).

b. Pengenalan pajak religius atau pemberian sedekah.

c. Pelarangan produksi barang dan jasa yang bertentangan dengan sistem nilai Islam (haram).

d. Penghindaran aktivitas ekonomi yang melibatkan maysir (judi) dan gharar (ketidakpastian)

\section{Unsur-unsur Pembiayaan}

a. BMT

Merupakan badan usaha yang memberikan pembiayaan kepada pihak lain yang membutuhkan dana.

b. Mitra Usaha/Partner

Merupakan pihak yang mendapat pembiayaan dari BMT atau pengusaha dana yang disalurkan oleh BMT.

c. Kepercayaan (Trust)

BMT memberikan kepercayaan kepada pihak yang menerima pembiayaan bahwa mitra akan memenuhi kewajiban untuk mengembalikan dana BMT sesuai dengan jangka waktu tertentu yang diperjanjikan. BMT memberikan pembiayaan kepada mitra usaha sama artinya dengan BMT memberikan kepercayaan kepada pihak penerima pembiayaan, bahwa pihak penerima pembiayaan akad dapat memenuhi kewajibannya.

d. Akad
Akad merupakan kontrak perjanjian atau kesepakatan yang dilakukan antara BMT dan pihak anggota atau mitra usaha.

e. Risiko

Setiap dana yang disalurkan atau diinvestasikan oleh BMT selalu mengandung resiko tidak kembalinya dana. Resiko pembiayaan merupakan kemungkinan kerugian yang akan timbul karena dana yang disalurkan tidak dapat kembali.

f. Jangka waktu

Merupakan periode waktu yang diperlukan oleh anggota untuk membayar kembali pembiayaan yang telah diberikan oleh BMT. Jangka waktu dapat bervariasi antara lain jangka pendek, jangka menengah dan jangka panjang. Jangka pendek adalah jangka waktu pembayaran kembali pembiayaan hingga satu tahun.Jangka menengah merupakan jangka watu yang diperlukan dalam melakukan pembayaran kembali antara satu hingga tiga tahun.Jangka panjang adalah jangka waktu pembayaran kembali pembiayaan yang lebih dari tiga tahun.

g. Balas Jasa

Sebagai balas jasa atas dana yang disalurkan oleh BMT, maka anggota membayar sejumlah tergantung sesuai dengan akad yang telah disepakati antara BMT dan anggota

\section{Jenis-jenis Pembiayaan Syariah}

Jenis-jenis produk penyaluran 
dana adalah:

1. Pembiayaan Mudharabah

Menurut Antonio (2001:95), Al-

Mudharabah adalah akad kerja sama antara dua pihak di mana pihak pertama menyediakan $100 \%$ modal, sedangkan pihak lainnya menjadi pengelola. Keuntungan usaha secara mudharabah dibagi menurut kesepakatan yang dituangkan dalam kontrakManajemen BMT adalah profesional alamiMenurut

2. Pembiayaan Musyarakah

Suwiknyo (2009:103) mendefiniskan musyarakah sebagai akad kerja sama antara dua pihak atau lebih untuk usaha tertentu di mana masing-masing pihak memberikan kontribusi dana dengan kesepakatan bahwa keuntungan dan resiko akanditanggung bersama sesuai dengan kesepakatan dan seberapa besar kontribusi dana. Menurut Dewan Syariah Nasional MUI dan PSAK Np. 106 mendefinisikan musyarakah sebagai akad kerjasama antara dua pihak atau lebih untuk suatu usaha tertentu, di mana masing-masing pihak memberikan kontribusi dana dengan ketentuan dibagi berdasarkan kesepakatan sedangkan kerugian berdasarkan kontribusi dana.

3. Pembiayaan Murabahah

Secara bahasa, murabahah berasal dari kata Ar-Ribhu yang berarti tumbuh dan berkembang, atau murabahah juga berarti Al-Irbaah, karena salah satu dari dua orang yang bertransaksi memberikan keuntungan kepada yang lainnya (Rusyd, 1990:443).

4. Salam

Ulama Malikiyyah menyatakan salam adalah akad jual beli di mana modal (pembayaran) dilakukan secara tunai (di muka) dan obyek pesanan diserahkan kemudian dengan jangka waktu tertentu (Muhammad, 2000:5859).

5. Istisna'

Transaksi bai'al-istisna' dijelaskan Antonio (2001:113) merupakan kontrak penjualan antara pembeli dan pembuat barang dengan spesifikasi yang telah disepakati. Menurut jumhur fuqaha', bai'al-istisna' merupakan jenis khusus dari akad bai'as-salam.

6. Ijarah

Al-ijarah adalah akad pemindahan hak guna atas barang atau jasa melalui pembayaran upah sewa tanpa diikuti dengan pemindahan kepemilikan atas barang itu sendiri (sabiq, 2004:183).

7. Ijarah Muntahiyah Bi Tamlik

Menurut Sabiq (2004 : 272), ljarah Muntahiyah Bi Tamlik adalah transaksi sewa dengan perjanjian untuk menjual atau menghibahkan objek sewa di akhir periode sehingga transaksi ini diakhiri dengan kepemilikan objek sewa.

\section{Tujuan Pembiayaan}

Secara umum, tujuan pembiayaan adalah sebagai berikut: 
a. Peningkatan ekonomi umat, artinya masyarakat yang tidak dapat akses secara ekonomi, dengan adanya pembiayaan mereka dapat melakukan akses ekonomi. Dengan demikian, dapat meningkatkan taraf ekonominya.

b. Tersedianya dana bagi peningkatan usaha, artinya untuk pengembangan usaha membutuhkan dana tambahan. Dana tambahan ini dapat diperoleh melakukan aktivitas pembiayaan. Pihak yang surplus dana menyalurkan kepada pihak defisit dana, sehingga dapat tergulirkan.

c. Meningkatkan produktifitas, artinya adanya pembiayaan memberikan peluang bagi masyarakat usaha agar mampu meningkatkan produktifitasnya. Sebab upaya produksi tidak akan dapat berjalan tanpa adanya dana.

\section{METODE PENELITIAN}

\section{Pendekatan Penelitian}

Penelitian dapat dilakukan dengan pendekatan kualitatif.Pendekatan yang digunakan dalam penelitian ini adalah pendekatan kualitatif dengan metode studi kasus deskriptif.Studi kasus (case study) merupakan strategi yang cocok bila pokok pertanyaan penelitian berkenan dengan "how" atau "why", bila peneliti hanyamemiliki sedilkit peluang untuk mengontrol peristiwa-peristiwa yang akan diteliti, dan apabila peneliti terlibat langsung dalam penelitian, dan bila fokus penelitian terletak pada fenomena kontemporer (masa kini) di dalam konteks kehidupan nyata, serta terdapat proposisi di dalamnya (Yin, 2009:1).

\section{Ruang Lingkup Penelitian}

Rumusan masalah tersebut menjadi bahan acuan peneliti dalam menentukan ruang lingkup penelitian ini.Ruang lingkup penelitian terbatas pada bentuk pemberdayaan ekonomi pedagang kecil yang ada di sekitar BMT Padi Bersinar Utama melalui pembiayaan di bidang sektor riil. Ruang lingkup penelitan merupakan batasan studi yang menjelaskan fokus studi agar tidak melebar ke masalah lain dalam penelitian.

Penelitian ini membahas tentang Peran Pembiayaan Sektor Riil yang Diberikan oleh BMT Padi Bersinar Utama dalam Rangka Pemberdayaan Ekonomi Pedagang Kecil Pasar Pucang Surabaya. Pemberdayaan usaha pedagang kecil yang dimaksud dalam penelitian ini adalah bagaimana cara BMT Padi Bersinar Utama dalam memberdayakan pedagang kecil yang ada di sekitar wilayah BMT yang sudah memiliki usaha tapi masih membutuhkan modal ataupun pedagang kecil yang sama sekali belum memiliki modal untuk mendirikan usahanya tetapi mereka ingin membuka usaha melalui pembiayaan sektor riil yang diberikan oleh BMT Padi Bersinar Utama. Diharapkan dengan adanya program tersebut dapat meningkatkan volume usaha dari sebelumnya. 
Indikator pemberdayaan usaha kecil tersebut dapat dilihat dari sebelum dan sesudah menerima pembiayaan dilihat dari besarnya aset usaha, omzet usaha, pendapatan usaha, stabilitas usaha, dan modal yang didapat. BMT meningkatkan, membina, dan mendampingi pedagang kecil mengenai pengetahuan tentang akuntansi, manajemen, teknologi, pemasaran, administrasi, dan kevangan dari para pedagang kecil yang menjadi nasabah BMT yang diteliti, bagaimana peran BMT dalam memberdayakan usaha para pedagang kecil sebelum dan sesudah meneriman pembiayaan di bidang sektor riil dari BMT dilihat dari penggunaan alatalat keuangan, pemasaran, manajemen, administrasi, akuntansi dan teknologi beserta omzet serta laba yang didapat.

\section{Prosedur Pengumpulan Data}

Penelitian ini membutuhkan dua sumber data yaitu data primer dan data sekunder.Dalam pengumpulan kedua data tersebut memiliki prosedur yang berbeda antara data primer dan sekunder. Data primer diperoleh melalui prosedur berikut :

\section{Persiapan awal}

Pada tahap ini, peneliti mengurus surat ijin penelitian skripsi secara formal pada bagian akademik Fakultas Ekonomi Bisnis Universitas Airlangga sebagai berkas pelengkap dalam melakukan penelitian di BMT Dinar Utama. Tujuan dari ijin penelitian ini adalah untuk mempermudah menggali informasi dan data yang mendalam pada BMT yang berhubungan dengan penelitian untuk dijadikan kerangka dasar penelitian.

2. Proses Memasuki Lokasi Penelitian

Pada tahap ini peneliti menemui pimpinan BMT Dinar Utama Jawa Timur dengan membawa surat ijin penelitian.

3. Saat di Lokasi Penelitian

Pada tahap ini, peneliti menjelaskan maksud, tujuan dan ijin untuk melakukan penelitian kepada BMT Dinar Utama Jawa Timur untuk kemudian melakukan observasi partisipasif dan wawancar secara mendalam dengan pimpinan dan beberapa pengelola untuk menggali informasi tentang situasi dan kondisi BMT Dinar Utama Jawa Timur saat ini secara umum serta menggali data yang berkaitan dengan penyaluran dana BMT, akad yang digunakan, dan peran BMT Dinar Utama Jawa Timur dalam meningkatkan kesejahteraan pelaku UMKM di kota Surabaya. Observasi dilakukan secara terus menerus secara berkala selama beberapa hari sampai peneliti menemukan gambaran umum sebagai dasar kerangka teori penelitian dan fokus penelitian.

4. Saat Pengumpulan Data

Pada saat ini, peneliti melakukan wawancara dan observasi partisipatif langsung kepada beberapa pelaku masyarakat yang menerima dana pembiayaan dari BMT Dinar Utama 
Jawa Timur. Hal ini dilakukan untuk mendapat jawaban atas rumusan masalah yang ada. Hasil dari wawancara dan observasi partisipatif dari objek penelitian didokumentasikan sendiri oleh peneliti untuk kemudian diolah dan dianalisis.

Sedangkan data sekunder yang digunakan untuk mendukung penelitian ini diperoleh melalui prosedur sebagai berikut:

1. Studi kepustakaan, yaitu data-data yang diperoleh dari jurnal-jurnal skripsi terdahulu, penelitianpenelitian, makalah, buku-buku pustaka, mengikuti perkuliahan tentang Baitul Mal Wat Tamwil, dan referensi lain yang bersangkutan.

2. Data internet, melalui search engine pada situs-situs yang relevan tentang Baitul Mal Wat Tamwil.

\section{Validasi Data}

Penelitian ini berada dalam tahap validasi data peneliti menggunakan pengujian triangulasi. Menurut Sugiono (2007:464) triangulasi dalam pengujian kredibilitas diartikan sebagai pengecekan data dari berbagai sumber dengan berbagai cara,dan berbagai waktu. Dengan demikian terdapat triangulasi sumber, triangulasi teknik pengumpulan data, dan triangulasi waktu:

1. Triangulasi Sumber

2. Triangulasi Teknik

\section{Teknik Analisis Data}

Tekhnik analiis data dalam penelitian ini akan dilakukan dengan pendekatan analisis kualitatif deskriptif. Analisis yang digunakan adalah membandingkan suatu temuan dan kajian proposisi yang telah dibuat sebelumnya. Tujuan dari perbandingan tersebut adalah menganalisis data studi kasus dengan cara membuat suatu penjelasan (naratif), dan menggambarkan (mendeskripsikan) kasus yang bersangkutan dan membuktikan proposisi teoritis yang telah dibuat.

Semua tekhnik analisis data kualitatif berkaitan erat dengan metode pengumpulan data, yaitu observasi dan wawancara.Bahkan terkadang suatu teori yang dipilih berkaitan secara tekhnis dengan metode pengumpulan data dan metode analisis data karena teori biasanya pula menyediakan prosedur metode dari prosedur analisis data dengan demikian, pengumpulan data dilakukan (wawancara, dan observasi) melalui tradisi analisis data tersebut (Bungin, 2008:78).Penelitian ini menggunakan metode analisis data berupa deskriptif kualitatif.

\section{HASIL DAN PEMBAHASAN}

\section{Deskripsi Hasil Penelitian}

\section{Profil BMT Padi Bersinar Utama Surabaya}

Koperasi BMT Padi Bersinar Utama adalah lembaga keuangan yang dikelola oleh Pimpinan Wilayah Nasyiatul Aisyiah Jawa Timur, yang berawal dari kemirisan hati pimpinan wilayah Nasyiatul Aisyiah melihat merebaknya para rentenir yang ada di masyarakat.

Koperasi BMT Padi Bersinar Utama 
(DINAR) didirikan pada tahun 1998 oleh 25 anggota Nasyiatul Aisyiah Jawa Timur dengan modal awal Rp 5.000.000,- (Rp 2.800.000,- dari modal PWNA dan Rp 2.200.000,- dari hasil iuran pendiri) yang berfungsi untuk meningkatkan dan mengembangkan kehidupan dan kesejahteraan sosial ekonomi umat serta sebagai sarana dakwah Islam.

Koperasi BMT Padi Bersinar Utama (DINAR) adalah lembaga keuangan yang dikekola oleh Pimpinan Wilayah Nasyiatul 'Aisyiyah Jawa Timur yang berfungsi untuk meningkatkan dan mengembangkan kehidupan dan kesejahteraan sosial ekonomi umat serta sebagai sarana dakwah. Koperasi BMT DINAR menerapkan sistem

Koperasi BMT Dinar Utama yang mulai beroperasi pada tanggal 11 November 2001 dengan BH 10/BH/436413/IV/2004 adalah sebuah jelmaan dari BMT Dinar PWNA yang dirintis sejak bulan Maret 1998.

Koperasi BMT Dinar Utama mulai beroperasi dengan modal yang dimiliki oleh koperasi. Pengurus dan pengelola bertekad untuk menggali dana dari masyarakat melalui tabungan harian, tabungan idul fitri (parcel), memperbanyak anggota koperasi (simpanan pokok dan simpanan wajib) dan memperluas wilayah kerja koperasi BMT Dinar Utama. Koperasi BMT Dinar Utama bekerja sama dengan koperasi As Sakinah Sidoarjo dalam keuangan dan pengadaan barang. Selain itu koperasi
BMT Dinar Utama juga mempunyai koperasi binaan, yaitu koperasi BMT Dinar Bojonegoro (Buana PDNA Kabupaten Bojonegoro).

\section{Motto dan Visi Misi}

Sesuai dengan status sebagai koperasi jasa keuangan syari' ah, BMT Padi Bersinar Utama (DINAR) Surabaya memiliki visi yaitu menjadi koperasi yang sehat, mandiri, dan tangguh berdasarkan prinsip syariah. Visi diatas kemudian dijabarkan menjadi beberapa misi yaitu:

1. Membangun lembaga ekonomi yang sehat, tangguh, mandiri, dan profesional.

2. Memberdayakan para pelaku usaha mikro dan kecil dalam usaha dan akses permodalan.

\section{Produk\&Layanan BMT Dinar Utama Surabaya}

Secara umum BMT Padi Bersinar Utama Surabaya memiliki 2 macam produk, yaitu produk simpanan dan produk pembiayaan, yakni :

a. Produk Simpanan

BMT Dinar Utama Surabaya memiliki produk simpanan yang cukup beragam guna memenuhi kebutuhan masing-masing anggota. Produk simpanan di BMT Dinar Utama dibagi menjadi 2 yaitu simpanan harian dan simpanan berjangka.

b. Simpanan Harian

Simpanan harian adalah simpanan yang diperuntukkan bagi anggota, calon anggota dan anggota 
partisipan yang penyetoran dan penarikannya dapat dilakukan sewaktu-waktu untuk membantu menyiapkan kebutuhan keuangan yang aman dan terencana

c. Simpanan Berjangka

Simpanan berjangka adalah simpanan yang dipersiapkan untuk investasi dan rencana kebutuhan yang akan datang dan hanya boleh diambil pada waktu yang telah disiapkan oleh Shahibul Maal (pemilik dana) dan Mudharib (pengelola dana)

\section{Produk Pembiayaan BMT Dinar Utama}

Terdapat 5 produk layanan pembiayaan pada KJKS BMT Dinar Utama yaitu :

1. Pembiayaan Mudhorobah ( modal kerja 100\% BMT )

BMT Dinar Utama selaku pemilik dana memberikan pembiayaan $100 \%$ untuk modal usaha kepada anggota selaku pengelola dana. Nisbah bagi hasil dari keuntungan disepakati kedua belah pihak.

2. Pembiayaan Musyarokah

BMT Dinar Utama hanya membiayai sebahagian saja dari kebutuhan modal usaha peminjam. Bagi hasil dari keuntungan disepakati oleh kedua belah pihak.

3. Pembiayaan Murobahah

Pembiayaan oleh BMT Dinar Utama pada pembelian barang dengan harga pokok kemudian disepakati harga jualnya dan peminjam membayar kepada BMT Dinar Utama pada waktu yang telah disepakati.

4. Bai' Bitsaman Ajil (BBA)

Pembiayaan atas pembelian harga pokok suatu barang, disepakati harga jualnya peminjam membayar kepada BMT Dinar Utama secara angsuran dengan jangka waktu sesuai kesepakatan.

5. Qordhul Hasan

BMT Dinar Utama menerima zakat, infaq, dan shodaqoh yang akan disalurkan untuk program beasiswa bagi anak-anak berprestasi tapi kurang mampu, bantuan sosial kepada masyarakat yang tertimpa musibah dan lain-lain.

Terdapat beberapa produk layanan yang lainnya selain yang tersebut diatas pada KJKS BMT Dinar Utama yaitu :

a. Pembayaran Zakat, Infaq, dan Sodakoh

b. Pembayaran Listrik

c. Pembayaran Telepon

d. Transfer antar bank

e. Penjualan seragam, buku - buku, dan atribut Nasyiatul Aisyiyah

f. Penjualan sembako

\section{Prosedur Pembiayaan BMT Dinar Utama}

Latar belakang pemberian

pembiayaan ini adalah:

a. BMT Dinar Utama diharapkan untuk dapat memberikan kebutuhan kepentingan anggota baik untuk menunjang usaha maupun kesejahteraannya. Memberikan pelayanan dan pendampingan kepada usaha masyarakat skala kecil 
dan mikro untuk meningkatkan kesejahteraan dan kualitas hidup dan perekonomiannya.

b. Menciptakan budaya dan mendekatkan masyarakat pada lembaga keuangan syariah dan bertransaksi muamalah secara syariah. Dengan sasaran pembiayaan adalah lingkup pasar pembiayaan usaha skala kecil yang masih potensial dan diberikan untuk usaha yang bersifat produktif dan konsumtif.

\section{Hasil Penelitian}

Peran BMT Padi Bersinar Utama Surabaya dalam Pemberdayaan Usaha Pedagang Kecil Pasar Pucang Surabaya Melalui Pelatihan, Pendampingan dan Pembinaan Setelah dilakukan wawancara kepada 4 (empat) orang responden yang mewakili anggota BMT Padi Bersinar Utama Surabaya, diperoleh hasil bahwa semua responden tersebut setuju atau bersedia dan tertarik dengan pelatihan, pendampingan dan pembinaan oleh menegement BMT Padi Bersinar Utama Surabaya.

Selama ini para pedagang merasa bertambah pengetahuan dan informasi dengan adanya kegiatan pelatihan, pendampingan dan pembinaan tersebut. Adanya interaksi antara anggota pembiayaan BMT pelatihan, pendampingan dan pembinaan dengan pihak BMT pelatihan, pendampingan dan pembinaan pada saat pengambilan angsuran pembiayaan juga mampu menjadi salah satu kesempatan bagi menegement BMT Padi Bersinar Utama Surabaya untuk mengetahui kondisi anggota termasuk meberikan motivasi dan saran apabila kondisi dilapangan dirasa kurang baik.

Secara keseluruhan BMT Padi Bersinar Utama Surabaya telah berusaha melaksanakan peran dalam pemberdayaan pedagang kecil tidak hanya sebatas pembiayaan modal. Peran pemberdayaan melalui pelatihan, pendampingan dan pembinaan harus terus ditingkatkan oleh BMT Padi Bersinar Utama Surabaya agar tujuan mensejahterakan anggota binaan bisa tercapai dengan cepat dan tepat.

Peran BMT Padi Bersinar Utama Surabaya dalam Pemberdayaan Usaha Pedagang Kecil Pasar Pucang Surabaya Melalui Pembiayaan

Peran yang dilakukan oleh BMT Padi Bersinar Utama adalah dengan memberikan pembiayaan modal usaha kepada anggota BMT untuk menyewa gerai, membeli bahan dagangan dan lain-lain dengan menggunakan akad pembiayaan murabahah dimana anggota diberikan kekuasaan untuk memenuhi kebutuhanya. Peran BMT Padi Bersinar Utama dalam pemberdayaan usaha pertanian dapat dilihat dari beberapa indikator yaitu terpenuhinya modal, peningkatan pendapatan dan mengurangi angka kemiskinan. Peran BMT Padi Bersinar Utama dapat dilihat pada tabel di bawah ini: 
Tabel 2.

Total Pembiayaan BMT Padi Bersinar

Utama

\begin{tabular}{|c|l|c|}
\hline $\begin{array}{c}N \\
0\end{array}$ & Jenis Pembiayaan & \multicolumn{1}{|c|}{ Jumlah } \\
\hline 1 & Pembiayaan ljaroh & 880.100 .000 \\
\hline 2 & $\begin{array}{l}\text { Pembiayaan } \\
\text { Murabahah }\end{array}$ & 1.204 .000 .000 \\
\hline 3 & $\begin{array}{l}\text { Pembiayaan } \\
\text { Mudharabah }\end{array}$ & 285.000 .000 \\
\hline & Total Pembiayaan & 2.369 .100 .000 \\
\hline
\end{tabular}

Sumber: Data Primer (Diolah) 2019

Dapat dilihat dari tabel di atas pembiayaan yang sering dilakukan dalam BMT Padi Bersinar Utama yaitu pembiayaan dengan akad Murabahah dengan total pembiayaan sebesar Rp. 1.204.000.000 atau sebesar 50,82\%. Pembiayaan dengan akad ijaroh berada pada posisi kedua dengan total pembiayaan sebesar Rp.880.100.000 atau sebesar $37,14 \%$ dan paling kecil peminatnya adalah pembiayaan dengan akad mudharabah dengan total pembiayaan Rp. 285.000 .000 atau sebesar $12,02 \%$.

Tabel 3.

Peningkatan Pendapatan Usaha Para Informan Penerima Pembiayaan di BMT

Padi Bersinar Utama

\begin{tabular}{|c|c|c|c|c|}
\hline \multirow[b]{2}{*}{0} & \multirow[b]{2}{*}{$\begin{array}{c}\text { Anggot } \\
a\end{array}$} & \multicolumn{2}{|c|}{ Pendapatan } & \multirow[b]{2}{*}{$\begin{array}{c}\text { Ketera } \\
\text { ngan }\end{array}$} \\
\hline & & $\begin{array}{c}\text { Sebelu } \\
\mathrm{m}\end{array}$ & $\begin{array}{c}\text { Sesuda } \\
\mathrm{h}\end{array}$ & \\
\hline 1 & $\begin{array}{l}\text { Pedag } \\
\text { ang } 1\end{array}$ & 2.000 .00 & 2.500 .00 & $\begin{array}{c}\text { Menin } \\
\text { gkat }\end{array}$ \\
\hline
\end{tabular}

\begin{tabular}{|c|c|c|c|c|}
\hline & & 0 & 0 & \\
\hline 2 & $\begin{array}{l}\text { Pedag } \\
\text { ang } 2\end{array}$ & $\begin{array}{l}1.750 .00 \\
0\end{array}$ & $\begin{array}{l}2.100 .00 \\
0\end{array}$ & $\begin{array}{c}\text { Menin } \\
\text { gkat }\end{array}$ \\
\hline 3 & $\begin{array}{l}\text { Pedag } \\
\text { ang } 3\end{array}$ & $\begin{array}{l}1.850 .00 \\
0\end{array}$ & $\begin{array}{l}2.000 .00 \\
0\end{array}$ & $\begin{array}{c}\text { Menin } \\
\text { gkat }\end{array}$ \\
\hline 4 & $\begin{array}{l}\text { Pedag } \\
\text { ang } 4\end{array}$ & $\begin{array}{l}2.050 .00 \\
0\end{array}$ & $\begin{array}{l}2.250 .00 \\
0\end{array}$ & $\begin{array}{c}\text { Menin } \\
\text { gkat }\end{array}$ \\
\hline
\end{tabular}

menunjukan bahwa, pembiayaan yang diberikan BMT Padi Bersinar Utama kepada anggota mampu memberikan dampak berupa peningkatan pendapatan dari sebelum mendapatkan pembiayaan. Rata - rata satu dari empat informan menyatakan bahwa pendapatan mereka meningkat dari sebelumnya dikarenakan penjualan dan dagangan yang ditambah tetapi juga informan menyatakan yang mereka dapatkan kadang juga tidak menentu tergantung dari kondisi jualannya. Mereka tidak terlalu mementingkan besar pendapatan usahanya yang diterima setiap harinya, mereka lebih cenderung mementingkan pendapatan mereka yang didapat dari hasil usahanya mampu mencukupi kebutuhan sehari-hari dan rumah tangganya. Selain itu dengan meningkatnya pendapatan para anggota BMT Dinar mereka juga dapat membayar angsuran pinjaman mereka dengan lancar dan juga menyisihkan sebagian dari pendapatan untuk ditabung. 
Peran BMT Padi Bersinar Utama Surabaya dalam Pemberdayaan Usaha Pedagang Kecil Pasar Pucang Surabaya Melalui Simpanan

Dalam upaya peningkatan pemberdayaan pedagang kecil, BMT Padi Bersinar Utama Surabaya tidak hanya memberikan pelayanan dalam hal pembiayaan dan pelatihan anggota binaan. BMT Padi Bersinar Utama Surabaya juga memberikan pelayanan bagi para anggota dalam hal simpanan. Hal ini dapat dibuktikan dengan adanya program simpanan yang disediakan oleh BMT Padi Bersinar Utama Surabaya. BMT Dinar Utama Surabaya memiliki produk simpanan yang cukup beragam guna memenuhi kebutuhan masing-masing anggota. Produk simpanan di BMT Dinar Utama dibagi menjadi 2 yaitu simpanan harian dan simpanan berjangka. Berikut ini adalah data yang diperoleh dari lapangan mengenai daftar anggota binaan yang menggunakan pelayanan simpanan pada BMT Padi Bersinar Utama Surabaya.

Tabel 4.

Data Anggota Simpanan

\begin{tabular}{|c|l|c|}
\hline No & Jenis Simpanan & $\begin{array}{c}\text { Persentase } \\
\text { Anggota }\end{array}$ \\
\hline 1 & Simpanan Harian & $76 \%$ \\
\hline 2 & $\begin{array}{l}\text { Simpanan } \\
\text { Berjangka }\end{array}$ & $24 \%$ \\
\hline
\end{tabular}

Sumber : data primer (diolah ) 2019

Berdasarkan data diatas dapat diketahui bahwa sebagian besar anggota binaan BMT Padi Bersinar Utama Surabaya memilih melakukan simpanan harian. Alasan mereka adalah simpanan harian dirasa lebih mudah dan tidak terikat waktu, selain dengan nilai simpanan yang tidak terlalu besar.

\section{Peran Baitul Maal Wat Tamwil dalam Pemberdayaan Usaha Pedagang Kecil}

Hasil dari analisis yang dilakukan peneliti dari wawancara dan observasi langsung adalah BMT Padi Bersinar Utama dalam memberikan pembiayaan pada pedagang kecil bisa dikatakan mampu memberdayakan atau meningkatkan usaha pedagang kecil secara optimal. Berdasarkan data dan informasi yang peneliti temukan di lapangan, adanya program pembiayaan yang ditujukan kepada masyarakat kecil yang sudah memiliki usaha tapi masih membutuhkan bantuan modal dalam meningkatkan volume usahanya tanpa adanya bunga serta persyaratan yang mudah. Selain memberikan pembiayaan dalam bentuk produktif adapula pembiayaan yang sifatnya konsumtif yakni untuk memenuhi kebutuhan primer kepada masyarakat kecil yang dirasa memerlukan tambahan untuk kebutuhan mendesaknya.

Peran BMT di bidang penyaluran dana kepada anggota yang bergerak pada usaha mikro kecil menengah perlu dioptimalkan. Karena tidak dipungkiri bahwa sektor ekonomi riil ini adalah sektor yang vital bagi perekonomian, okeh karena itu dengan adanya BMT menjembatani kesulitan dari belum terjamahnya usaha mikro kecil menengah 
Oleh bank-bank konvensional dengan memberikan pembiayaan kepada para pelaku usaha kecil. Dalam menjalankan misi tersebut yaitu dengan memberdayakan usaha para pedagang kecil dengan meningkatkan usaha mereka melalui program pembiayaan. Karena BMT memiliki peran sebagai berikut yaitu mengurangi rentenir, memberikan pembiayaan dan menyediakan tabungan kepada setiap anggota, angsuran yang fleksibel, adanya hubungan kekeluargaan yang erat dan pelaksanaan fungsi sosial.

Dengan adanya pembiayaan yang ada di BMT Padi Bersinar Utama Surabaya yang bertujuan untuk memberdayakan usaha pedagang kecil ini telah mampu membawa mereka yang sebelumnya masih kurang dan sulit terkait soal permodalan hinnga dapat menjembatani hal tersebut. Hal tersebut dapat dilihat dari peningkatan usaha para anggotanya seperti pendapatan usaha. Selain itu para penerima pembiayaan dilatih untuk bertanggung jawab terhadap dana yang diterimanya dan dapat dijadikan motivasi agar taraf hidupnya meningkat. Peminjam harus disadarkan tentang pentingnya penataan struktur keuangan, pinjaman kredit harus diartikan sebagai suntikan modal yang bersifat sementara karena pemberian pembiayaan harus mampu mendorong produksi yang akhirnya akan meningkatkan kapasitas usaha kecil yang berarti meningkatkan pendapatan dan meningkatkan kesejahteraan.

\section{SIMPULAN}

Berdasarkan hasil dan pembahasan penelitian tersebut, dapat ditarik beberapa kesimpulan yaitu:

1. BMT Padi Bersinar Utama yang merupakan Koperasi Jasa Keuangan Syariah tersebut telah berperan terhadap pemberdayaan usaha pedagang kecil di Pasar Pucang. Terlihat dari peningkatan usaha secara bertahap. Peningkatan usaha pada anggota BMT Padi Bersinar Utama juga berdampak kepada pembayaran angsuran yang lancar, meningkatkan tabungan mereka, dan kesadaran untuk membayar Zakat, Infaq, dan Shodaqoh.

2. Baitul Maal Wat Tamwil yang dikelola dengan berpegang teguh pada ajaran Islam, mampu menjelaskan fungsinya dan perannya dengan baik sebagai Lembaga Mikro Islam yang optimal.

3. BMT Padi Bersinar Utama telah mampu memberikan sosialisasi dan edukasi mengenai adanya BMT, sehinnga banyak anggota pasar yang menjadi target BMT itu sendiri yang menjadi anggota, terutama pada pedagang kecil yang membutuhkan modal usaha.

\section{Saran}

1. Bagi BMT, sebaiknya lebih dikembangkan lagi pemberian keterampilan secara rutin yang meliputi skiil dalam bidang perdagangan 
kepada anggota BMT. Agar anggota BMT tidak hanya menerima tambahan modal tetapi mereka juga mempunyai keterampilan di bidang lain, seperti pencatatan arus kas, penrhitungan laba rugi dan lain sebagainya. Dan perlu diadakan pula kajian muslim secara rutin kepada anggota BMT dan pengurus BMT agar mereka mendapat siraman rohani yang berguna bagi umat muslim. Selain itu, agar pihak BMT Padi Bersinar Utama lebih banyak memberikan perhatian lebih kepada pedagang-pedagang tersebut guna menghidupkan dan mengembangkan sektor riil di sekitar BMT Padi Bersinar Utama Surabaya. Selain itu, BMT Padi Bersinar Utama Surabaya diharapkan dapat menambah dan mengembangkan sektor riil yang telah diberdayakan sehingga lebih dapat meningkatkan peran BMT Padi Bersinar Utama Surabaya sebagai penggerak ekonomi rakyat dan bagi pihak anggota maupun masyarakat dapat memperbaiki ekonomi dan kesejahteraan dari berbagai aspek usaha.

2. Bagi anggota hendaknya mengetahui tentang produk-produk yang ditawarkan oleh pihak BMT Padi Bersinar Utama Surabaya secara mendetail agar dapat mengetahui fungsi, manfaat, serta keuntungan yang didapat bila terlibat dengan produk-produk keuangan, terutama produk keuangan Islam sehingga dengan demikian perekonomian anggota dapat terjaga dengan baik dan para anggota dapat melakukan transaksi secara ekonomi syariah sesuai dengan syariat yang awalnya bertransaksi dengan menggunakan metode konvensional dapat berpindah ke lembaga kevangan syariah. Anggota BMT juga sebaiknya menghitung dari setiap transaksi yang ada setiap harinya agar dapat diketahui jumlah kekayaan dan kewajiban mereka.

3. Bagi peneliti selanjutnya, diharapkan agar bisa meneliti lagi secara mendalam tentang pemberdayaan usaha masyarakat kecil yang dilakukan oleh lembaga-lembaga Islam baik perbankan maupun non perbankan. Diharapkan dapat menyempurnakan dari apa yang dibahas didalam skripsi ini.

\section{DAFTAR PUSTAKA}

Amalia, Euis. 2009. Keadilan Distributif Dalam Ekonomi Islam Penguatan Peran LKM dan UKM di Indonesia. Jakarta: PT Raja Grafindo Persada.

Andriani. 2005. Baitul Mal Wat Tamwil (Konsep dan Mekanisme di Indonesia). Bandung: Pustaka Setia.

Antonio, Muhammad Syafi'i. 2001 .Bank Syariah dan Teori Praktik. Jakarta: Gema Insani.

Astuti, Evy.2007. Evaluasi Tingkat Pendapatan Usaha Kecil Sebelum 
dan Sesudah Memperoleh

Pembiayaan dari BMT Beringharjo

Kauman Yogyakarta. Skripsi Tidak

Diterbitkan. Fakultas Ekonomi

Universitas Islam Yogyakarta.

Aziz, Amin. 1995. Propek BMT Berbadan Hukum Koperasi.Majalah Disajikan Pada Seminar Propek BMT Berbadan Hukum Koperasi. Jakarta: Kerjasama PINBUK dengan Departemen Koperasi.

2008. Tata Cara Pendirian BMT. Jakarta: Pusat Komunikasi Ekonomi Syariah.

Bl, Agustus 2016.Usaha Mikro Islami. Jakarta: Departemen Ekonomi Dan Keuangan Syariah BI.

Buchori, Nur S. 2009. Koperasi Syariah Sidoarjo. Kelompok Media Buana Pustaka.

Bungin, Burham. 2001. Metode Penelitian Kualitatif. Jakarta: PT Raja Grafindo Persada. - 2008. Metode Penelitian Kualitatif. Jakarta: Kencana.

Chaniago, Aarifina dkk.1995.Ekonomi 2. Bandung: Angkasa.

Cokrohadisumarto dan Widiyanto Bin Mislan.2000.BMT Praktik dan Kasus. Jakarta: Raja Grafindo

Diola, Alfa.2011. Peran BMT Dalam Meningkatkan Kesejahteraan Anggota Pada BMT UGT Sidogiri di Kota Surabaya.Skripsi tidak diterbitkan.Fakultas Ekonomi dan Bisnis Universitas Airlangga Surabaya.
Efendi, A.Z. dkk. 2012. Demokrasi Ekonomi : Koperasi dan Pengembangan Ekonomi Kerakyatan. Jakarta: Program Sekolah Demokrasi Averroes Press.

Hamid, Edy Suandi dan Sri Susilo Y. 2011. Strategi Pembangunan Usaha Mikro Kecil dan Menengah Provinsi Daerah Istimewa Yogyakarta, Jurnal

Ekonomi Pembangunan, Vol. 12 No. 1 Juni, 2011 , hal 45-55.

Hutomo, Mardi Yatmo. 2000. Pemberdayaan Masyarakat Dalam Bidang Ekonomi: tinjauan Teoritik dan Implementasi. Jakarta: Bapennas.

Ilmi, Makhalul SM. 2002. Teori dan Praktek Lembaga Keuangan MikroSyariah.Yogyakarta: UII Press.

Jakarsih, Aan. 2008. Pengaruh Kemampuan Manajerial Pengusaha Terhadap Keberhasilan Usaha Pengusaha Sepatu di Sentra Industri Kecil Persepatuan Cibaduyut.Disertasi tidak diterbitkan. Bandung: FPIPS UPI.

Jumhur. 2006. Analisis Permintaan Kredit Modal Kerja Usaha Kecil di Kota Semarang (Studi Kasus Permintaan Modal Kerja Usaha Kecil Sektor Perdagangan dari BMT). Tesis tidak diterbitkan. Semarang: pascasarjana Universitas Diponegoro.

Karim, Adiwarman. 2001. Ekonomi Islam, Suatu Kajian Kontemporer. Jakarta: 
gema Insani.

Kartasasmita, Ginandjar. $\quad 1996$. Pembangunan Untuk Rakyat: Memadukan Pertumbuhan dan Pemerataan. Cides.

Kuncoro. 2008. Pembiayaan Usaha Kecil. Economic Review, no 211 (3): 1-10. Lubis,S.K. dan Wadji,F. 2014. Hukum Ekonomi Islam.Jakarta : Sinar Grafika.

Mubyarto. 1995. Pengantar Ekonomi Pertanian. Jakarta : LP3ES.

Muhammad. 2000. Sistem dan Prosedur Operasional Bank Syariah.Yogyakarta: UII Press.

- 2007. Lembaga Ekonomi Syariah. Yogyakarta : Graha Ilmu.

Moleong, Lexy J. 2000. Metode Penelitian Kualitatif. Bandung: PT Remaja Rosidakarya.

Norvadewi.2007. Tinjauan Syariah Terhadap Badan Hukum Koperasi Untuk Baitul Maal Wat Tamwil. Jurnal Mulahib 2 (IV) 193-204.

Nur Hasanah,N.2015. Mudharabah Dalam Teori Dan Praktik. Bandung : PT Refika Aditama.

Partomo dan Sartika,T. 2009. Ekonomi Koperasi Bandung : Ghalia.

Qardhawi, Yusuf. 1999. Hukum Zakat. Jakarta: PT Pustaka Litera Antar Nusa.

Ridwan, Muhammad. 2004. Manajemen Baitul Maal Wat Tamwil (BMT). Yogyakarta: UII Press.

Rustam, Efendi. 2003. Produksi Dalam Islam Cetakan 1. Yogyakarta: Magistra
Insania Press Bekerjasama dengan MSI UII.

Santoso, Ivan Rahmat. 2007. Peran BMT Dalam Pemberdayaan Ekonomi Sektor Riil (Studi Kasus Pada BMT Haniva Imogiri Yogyakarta) Tesis Tidak Diterbitkan. Yogyakarta: Magister Studi Islam Universitas Islam Indonesia Yogyakarta.

Sari, Nur Livia, 2015.Peran Wakaf Tunai Dalam Pemberdayaan Mauquh Alaih (Studi Kasus BMT Amanah Ummah) .Skripsi tidak diterbitkan: Fakultas Ekonomi dan Bisnis Universitas Airlangga Surabaya.

Satria, W.L.M. Oktober 2004.Merebut Hati Rakyat Melalui

Nasionalisme, Demokrasi

Dan

Pembangunan

Ekonomi

Sumbangan Pemikiran Abu Rizal Bakrie. Jakarta : PT Prima Media Pustaka - PT Gramedia.

Sarwono, Sarlito Wirawan. 2006. Teori-Teori Psikologi Sosial Edisi Revisi 12. Jakarta: PT. Raja Grafindo Persada.

Sholihin, Ahmad Ifham. 2010. Buku Pintar Ekonomi Syariah. Jakarta: PT Gramedia.

Soekanto, Soerjono. 1982. Sosiologi Suatu Pengantar. Jakarta : CV Rajawali.

Soemitra, Andri. 2009. Bank dan Lembaga Kevangan Syariah. Jakarta:Kencana.

Subagyo, A. 2015.Keuangan Mikro Syariah. Jakarta: Mitra Wacana Media.

Sudarsono,H. 2003. Bank Dan Lembaga Keuangan Syariah Deskripsi Dan 
Ilustrasi. Yogyakarta: Ekonisia Kampus FE UII.

2007. Bank dan Lembaga Keuangan Syariah. Deskripsi dan Ilustrasi. Yogyakarta: Ekonisia FE UII.

Sugiyono. 2005. Memahami Penelitian Kualitatif. Bandung: PT Remaja Rosidakarya.

2008. Memahami Penelitian Kualitatif. Bandung: PT Remaja Rosidakarya. 2009. Memahami Penelitian Kualitatif. Bandung: PT Remaja Rosidakarya.

2010. Memahami Penelitian Kualitatif. Bandung: PT Remaja Rosidakarya.

Sumodiningrat, G. Oktober 2011. Membangun Perekonomian Rakyat. Yogyakarta : Pustaka Pelajar - IDEA Cet: 2.

Swastha, Basu. 1983. Manajemen Pemaaran Modern. Bandung: Liberty.

Tunggal, Amin Widjaja. 2002. Akuntansi Perusahaan Kecil dan Menengah. Jakarta: PT Rineka Cipta.

Wardhani, Nurvita Kusuma. 2013. Studi Eksplanatif Tentang Pengaruh Pengembangan Kapasitas Usaha Terhadap Tingkat Kesejahteraan Ekonomi Pengusaha di Sentra Industri Kecil Alas Kaka Wedoro Kecamatan Waru Sidoarjo. Jurnal Kebijakan dan Manajemen
Publik.Volume 1 Nomor 1.

Widodo, Hertanto dkk.1999. Panduan Praktis Operasional Baitul Maal Wat Tamwil.Bandung: Mizan.

Wie, K.T. Desember 1981. Pembangunan Ekonomi Dan Pemerataan Jakarta : Grafitas, LP3ES.

Yin, Robert. 2002. Studi Kasus : Desain dan Metode. Jakarta: Raja Grafindo Persada.

2003.Studi Kasus : Desain dan Metode. Jakarta: Raja Grafindo Persada.

2012. Studi Kasus : Desain dan Metode. Jakarta: Raja Grafindo Persada.

Zainul, Arifin. 1999. Memahami Bank Syariah, Lingkup, Peluang, Tantangan, dan Prospek. Jakarta: Alvabet.

Zallum, Abdul Qodim. 1983. Al Amwal fi aulah Al Khilafah cetakan I. Beirut: Darul Al IImi Lin Malayin.

Zubaedi. November 2007. Wacana Pembangunan Alternatif Ragam Perspektif Pengembangan Dan Pemberdayaan Masyarakat. Jogjakarta: Cet 1 Ar.Ruzz Media.

www.economy okezone.com (online) diakses pada tanggal 25 September 2017

www.koperasisyariah.com (online) diakses pada tanggal 25 September 2017 www.Replubikaonline.com (online) diakses 16 Oktober 2017 